\title{
Evaluation of Management of Pre-Eclamptic Cases Admitted to Elshatby Maternity University Hospital
}

\author{
Nermeen Mohamed Hefila*, Tamer Mamdouh Abd Eldayem, \\ Hisham Adel El Fazari
}

Department of Obstetrics and Gynecology, Faculty of Medicine, University of Alexandria, Alexandria, Egypt

Email: *nermeenptsbasem81@gmail.com

How to cite this paper: Hefila, N.M., Eldayem, T.M.A. and El Fazari, H.A. (2021) Evaluation of Management of Pre-Eclamptic Cases Admitted to Elshatby Maternity University Hospital. Open Journal of Obstetrics and Gynecology, 11, 689-700.

https://doi.org/10.4236/ojog.2021.116064

Received: May 2, 2021

Accepted: June 8, 2021

Published: June 11, 2021

Copyright $\odot 2021$ by author(s) and Scientific Research Publishing Inc. This work is licensed under the Creative Commons Attribution International License (CC BY 4.0).

http://creativecommons.org/licenses/by/4.0/ (c) (i) Open Access

\begin{abstract}
Hypertensive diseases of pregnancy, mainly PET, consist of several diseases which are associated with increased morbidity and mortality rates both maternal and fetal wise. Its incidence among pregnant females is about 3\% $10 \%$. This study included 500 pregnant PET women, and they categorized to mild and severe forms, after exclusion of cases with essential hypertension, renal disease and SLE. All pregnant ladies underwent history taking, abdominal examination (general and local), obstetric ultrasound, Doppler ultrasound, laboratory investigations; treatment received (antihypertensive medications, magnesium sulphate $\left(\mathrm{MgSO}_{4}\right)$ and steroids) and finally follow up till delivery. Regarding complications, PET can result in serious fet$\mathrm{al} /$ neonatal or maternal complications. By the beginning of this study we started with 380 mild cases and 120 severe cases, but the end of the study 50 cases of mild PET were lost during follow up and 70 cases of mild PET converted into severe form. The aim of this study is to evaluate the management protocols of preeclamptic cases admired to Elshatby maternity hospital to minimize maternal and fetal morbidity and mortality. RESULTS: The results showed that the incidence of PET is significant in both young and old age, higher incidence of IUGR in sever PET, the use of corticosteroids and $\mathrm{MgSO}_{4}$ was significantly higher in sever cases. CONCLUSION: it's important to diagnose PET by repeated blood pressure measurement. The use of corticosteroids and $\mathrm{MgSO}_{4}$ is improving maternal and fetal outcomes significantly. The incidence of C.S. is higher towards prematurity in sever cases.
\end{abstract}




\section{Keywords}

Pre-Eclampsia, Preeclampsia Management, Elshatby Hospital

\section{Introduction}

\subsection{Epidemiology}

Pregnancy hypertensive diseases, including PET, can be present in different presentations which increased morbidity and mortality rates both maternal and fetal. The incidence in pregnant cases is about 3\% - 10\%. [1] [2] PET is one of the major causes of maternal fetal deaths worldwide but its less common in developed countries. It is the main cause of maternal ICU admission due to high maternal morbidity [3] [4].

Approximately $12 \%$ to $25 \%$ of fetal IUGR and SGA age infants as well as 15 to $20 \%$ of all preterm births are due to PET [3] [5].

\subsection{Preeclampsia/Eclampsia}

Preeclampsia is a main cause of maternal and fetal or neonatal mortality and morbidity [6]. The disorder complicates $5 \%-7 \%$ of all pregnancies [7].

It occurs after 20 weeks of pregnancy, most often near term, and can be superimposed on another hypertensive disorder. It is defined by the occurrence of hypertension plus proteinuria not previously existing. Although hypertension associated with protienuria is the main classical presentation of PET but some cases are presented with hypertension with multi end organ failure specially liver and kidney [8] [9].

Eclampsia is the severest form of PET with convulsions. It is defined as newly onset grand mal seizures in a pregnant with sever preeclampsia. It can occur antepartum, intrapartum or postpartum. It is often preceded by some dangerous signs, such as severe headaches and hyperreflexia, but it can occur suddenly without warning signs or symptoms [9].

\subsection{Role of Smoking in Preeclampsia}

Smoking was suggested to be a protective factor against preeclampsia. During pregnancy, smoking has been involved in lowering the circulating levels of the anti-angiogenic proteins such as soluble fms-like tyrosine kinase-1 (sFlt1) and sEng (soluble endoglins) and raises the concentrations of the pro-angiogenic placental growth factor protein (PGF) [10] [11]. Moreover, the protective property of smoking can be explained by the role of carbon monoxide that is produced during smoking. It acts by inhibiting the production of anti-angiogenic proteins by the placenta such as sFlt1 and by inhibiting necrosis of the placenta and programmed cell death known as apoptosis. Also, NO (nitric oxide), which present in cigarettes may cause vasodilation and hence so protect against PET [10] [12]. However, evidence suggests that carbon monoxide may be the main 
critical mediator. In addition, carbon monoxide is protecting the vessels from a lot of vascular disorders such as ischemia as well as reperfusion injuries [10] [13].

\subsection{Pathophysiology of Preeclampsia}

\subsubsection{Abnormal Remodeling of Uterine Vessels by Trophoblasts}

While the main pathophysiology of PET is abnormal placention but the clear understanding of the pathology is still unclear. The means by which abnormal placentation results in systemic dysfunction is an area of ongoing research.

In normal pregnancy, there should be normal invasion of cytotrophoblasts to the uterine arteries, the tunica media is destroyed and the maternal endothelium is replaced by 16 - 18 weeks of gestations. The fetal requirements of oxygen and food is transferred to him by the low resistance high capacity uterine vessels which previously were of high resistance low capacity [14].

In preeclampsia this process is impaired due to abnormal cytotrophoblastic invasion resulting in high resistance uterine vessels with Placental ischemia and multisystemic dysfunction.

Preeclampsia can therefore starts with abnormal placentation leading to placental ischemia and later on development of hypertension and proteinuria [15] [16].

However, the actual pathophysiology of preeclamptic toxemia is unclear.

\subsubsection{Haemodynamic Changes}

Placental hypoxia and ischemia is considered a key feature in the pathogenesis of preeclampsia. Following ischemia, the placenta releases soluble products into the serum of the mother which leads to endothelial dysfunction and antiangiogenic state. These products include sFltland sEng which have a major role in the inhibition of PGF and VEGF, vaso active endothelial growth factor, via bonding to these molecules in the maternal blood and target tissues as the kidneys. Moreover, an increase in Angiotensin-1 receptor lead to a rise in endothelin-1 and a drop in nitric oxide resulting in maternal hypertension, protienuria, endothelial dysfunction and oxidative stress [17] [18].

\section{Subjects}

This observational study was conducted on 500 pregnant women cases admitted to Shatby Maternity University Hospital from July 2019 to July 2020

All pregnant cases got full information about the study and informed consent was taken from each of them.

\subsection{Inclusion Criteria}

\subsubsection{Mild pre Eclampsia}

1) Systolic BP > $140 \mathrm{mmHg}$ and/or diastolic BP $>90 \mathrm{mmHg}$ on two separate times 6hours apart, occurring after 20 weeks gestation.

2) Proteinuria of $300 \mathrm{mg}$ in a 24 -hour urine collection or $>1+$ on two random sample urine dipsticks at least 6 hours apart. 


\subsubsection{Severe Pre Eclampsia}

1) Systolic BP $>$ or $=160 \mathrm{mmHg}$ and/or diastolic $\mathrm{BP}>110 \mathrm{mmHg}$ on two times at least 6 hours apart.

2) Proteinuria of $5 \mathrm{~g}$ or higher in 24-hour urine specimen or $3+$ or greater on two random urine samples collected with at least 4 hours interval.

3) Oliguria $<500 \mathrm{cc}$ in 24 hours.

4) Thrombocytopenia (platelet count $<100,000 / \mu \mathrm{L}$ ).

5) Elevated liver functions with persistent epigastric pain.

6) Pulmonary edema.

7) Persistent severe headache, drowsiness or visual disturbances.

\subsection{Exclusion Criteria}

1) Essential hypertension.

2) Renal disease.

3) Systemic lupus erythematosis.

\section{Methods}

\section{For the all cases, the following is done:}

1) Complete history taking (obstetric, medical, and surgical).

2) Complete general examination especially: general look, sites of edema, vitals (blood pressure, pulse rate, respiratory rate).

3) Complete obstetric examination.

4) Ultrasound examination: number of gestation, fetal biometry, amount of liquor and placenta.

5) Doppler findings: uterine arteries, umbilical artery, MCA Doppler and DVD.

6) Laboratory findings:

a) Routine investigations: $\mathrm{CBC}$, Creatinine, liver enzymes and uric acid.

b) Urinary dip sticks, twenty four hours urine protein or alblcreat. ratio.

7) Recording system:

a) Treatment given (antihypertensive drugs, magnesium sulphate, steriods and others).

b) Duration from admission till delivery.

c) Maternal and fetal outcome.

d) Other needed interventions.

e) Follow up till delivery.

Statistical analysis of the data [19]

Data were collected and analyzed using IBM SPSS software package version 20.0. (Armonk, NY: IBM Corp) [20].

\section{Results}

Description of the studied cases according maternal age and gestational age at admission:

Severe PET is significantly common among young women and old age. Gesta- 
tional age at time of admission is significantly lower in severe cases of PET (Table $1)$.

Description of the studied cases according to number of gestation and

\section{Liquor.}

Significantly higher incidence of PET in singleton than multiple pregnancies. Normal amount of liquor is significantly higher in mild cases but oligohydramnios is significantly higher in severe cases (Table 2).

Descriptive analysis of the studied cases according to viability and placenta:

Occurrence of IUFD (intrauterine fetal death) and abruptio placenta is significantly higher in severe PET (Table 3).

Description of the studied cases according to IUGR (intrauterine growth retardation):

IUGR is significantly higher in severe cases (Table 4).

Description of the studied cases according to treatment received:

Table 1. Comparative analysis between the two studied groups according to maternal age and gestational age.

\begin{tabular}{ccc} 
Total & \multicolumn{2}{c}{ Severity } \\
\cline { 2 - 2 }$(\mathrm{n}=500)$ & $\begin{array}{c}\text { Mild } \\
(\mathrm{n}=380)\end{array}$ & $\begin{array}{c}\text { Severe } \\
(\mathrm{n}=120)\end{array}$
\end{tabular}

Maternal age (years)

$\begin{array}{lcccrr}\text { Min. - Max. } & 16.0-45.0 & 19.0-40.0 & 16.0-45.0 & & \\ \text { Mean } \pm \text { SD. } & 28.74 \pm 6.25 & 28.65 \pm 4.46 & 29.05 \pm 10.01 & 0.427 & 0.670 \\ \text { Median } & 28.0 & 28.0 & 32.0 & & \end{array}$

Gestational age (weeks)

$\begin{array}{lccccc}\text { Min. - Max. } & 20.0-40.0 & 31.0-40.0 & 20.0-37.0 & & \\ \text { Mean } \pm \text { SD. } & 33.0 \pm 2.56 & 33.37 \pm 1.75 & 31.81 \pm 3.98 & 4.181^{\star} & <0.001^{\star} \\ \text { Median } & 33.0 & 34.0 & 33.0 & & \end{array}$

Table 2. Comparative analysis of the two studied groups according to number of gestation and liquor.

\begin{tabular}{lcccccccc}
\hline & \multicolumn{2}{c}{$\begin{array}{c}\text { Total } \\
(\mathrm{n}=500)\end{array}$} & \multicolumn{2}{c}{$\begin{array}{c}\text { Mild } \\
(\mathrm{n}=\mathbf{3 8 0})\end{array}$} & \multicolumn{2}{c}{$\begin{array}{c}\text { Severe } \\
(\mathrm{n}=120)\end{array}$} & $\chi^{2}$ & P \\
\cline { 2 - 6 } & No. & $\%$ & No. & $\%$ & No. & $\%$ & & \\
\hline $\begin{array}{l}\text { 1) Number of gestation } \\
\text { Singleton }\end{array}$ & 430 & 86.0 & 332 & 87.4 & 98 & 81.7 & & \\
$\quad \begin{array}{l}\text { Multiple } \\
\text { 2) Liquor }\end{array}$ & 70 & 14.0 & 48 & 12.6 & 22 & 18.3 & 240.463 & 0.01 \\
$\quad$ & & & & & & & & \\
Ok & 421 & 84.2 & 379 & 99.7 & 42 & 35.0 & & \\
$\quad$ Oligohydramnios & 79 & 15.8 & 1 & 0.3 & 78 & 65.0 & & \\
\hline
\end{tabular}


1) Steriods.

2) $\mathrm{MgSO}_{4}$

Only severe cases received $\mathrm{MgSO}_{4}$ (190 cases) 120 cases severe from the start and 70 mild cases who converted to severe form during their follow up. Severe cases which received steroids were significantly higher in number (Table 5).

Description of the studied cases according to mode of delivery:

The cases delivered by cesarian section (C.S.) were significantly higher in both groups. In this study 50 cases were excluded as they lost during their follow up (Table 6).

\section{Description of the studied cases according to maternal outcome;}

Table 3. Comparative analysis of the two studied groups according to viability and placenta.

\begin{tabular}{|c|c|c|c|c|c|c|c|c|}
\hline & \multicolumn{2}{|c|}{$\begin{array}{c}\text { Total } \\
(n=500)\end{array}$} & \multicolumn{2}{|c|}{$\begin{array}{c}\text { Mild } \\
(n=380)\end{array}$} & \multicolumn{2}{|c|}{$\begin{array}{c}\text { Severe } \\
(n=120)\end{array}$} & \multirow{2}{*}{$\chi^{2}$} & \multirow[t]{2}{*}{$\mathbf{P}$} \\
\hline & No. & $\%$ & No. & $\%$ & No. & $\%$ & & \\
\hline \multicolumn{9}{|l|}{ 3) Viability } \\
\hline Dead & 67 & 13.4 & 0 & 0.0 & 67 & 55.8 & \multirow{2}{*}{$244.996^{*}$} & \multirow{2}{*}{$<0.001^{\star}$} \\
\hline Viable & 433 & 86.6 & 380 & 100.0 & 53 & 44.2 & & \\
\hline \multicolumn{9}{|l|}{ 4) Placenta } \\
\hline Normal & 420 & 84.0 & 380 & 100.0 & 40 & 33.3 & \multirow{2}{*}{$301.587^{*}$} & \multirow{2}{*}{$<0.001^{\star}$} \\
\hline Abruptio placenta & 80 & 16.0 & 0 & 0.0 & 80 & 66.7 & & \\
\hline
\end{tabular}

Table 4. Comparative analysis of the two studied groups according to IUGR.

\begin{tabular}{|c|c|c|c|c|c|c|c|c|}
\hline & \multicolumn{2}{|c|}{$\begin{array}{c}\text { Total } \\
(\mathrm{n}=500)\end{array}$} & \multicolumn{2}{|c|}{$\begin{array}{c}\text { Mild } \\
(\mathrm{n}=380)\end{array}$} & \multicolumn{2}{|c|}{$\begin{array}{c}\text { Severe } \\
(\mathrm{n}=120)\end{array}$} & \multirow{2}{*}{$\chi^{2}$} & \multirow{2}{*}{$\mathrm{p}$} \\
\hline & No. & $\%$ & No. & $\%$ & No. & $\%$ & & \\
\hline \multicolumn{9}{|l|}{ IUGR } \\
\hline Absent & 405 & 81.0 & 380 & 100 & 25 & 20.8 & \multirow{2}{*}{$371.39^{\star}$} & \multirow{2}{*}{$<0.001^{\star}$} \\
\hline Present & 95 & 19.0 & 0 & 0.0 & 95 & 79.2 & & \\
\hline
\end{tabular}

Table 5. Comparative analysis of the two studied groups according to magnesium sulphate $\left(\mathrm{MgSO}_{4}\right)$ and steroids.

\begin{tabular}{|c|c|c|c|c|c|c|c|c|}
\hline \multirow[t]{2}{*}{ Treatment received ( $R \mathbf{x})$} & \multicolumn{2}{|c|}{$\begin{array}{c}\text { Total } \\
(\mathrm{n}=500)\end{array}$} & \multicolumn{2}{|c|}{$\begin{array}{c}\text { Mild } \\
(\mathrm{n}=380)\end{array}$} & \multicolumn{2}{|c|}{$\begin{array}{c}\text { Severe } \\
(n=120)\end{array}$} & \multirow{2}{*}{$\begin{array}{c}\text { Test of } \\
\text { Sig. }\end{array}$} & \multirow[t]{2}{*}{$\mathbf{P}$} \\
\hline & No. & $\%$ & No. & $\%$ & No. & $\%$ & & \\
\hline \multicolumn{9}{|l|}{$\mathrm{MgSO}_{4}$} \\
\hline Not received & 310 & 62.0 & 310 & 81.6 & 0 & 0.0 & \multirow{2}{*}{$257.618^{\star}$} & \multirow{2}{*}{$<0.001^{\star}$} \\
\hline Received & 190 & 38.0 & 70 & 18.4 & 120 & 100.0 & & \\
\hline \multicolumn{9}{|l|}{ Steroids } \\
\hline Not received & 317 & 63.4 & 302 & 79.5 & 15 & 12.5 & $10.336^{\star}$ & $0.001^{\star}$ \\
\hline Received & 183 & 36.6 & 78 & 20.5 & 105 & 87.5 & & \\
\hline
\end{tabular}


Among 450 cases of PET with good follow up there were 20 cases of eclampsia, 93 cases of HELLP syndrome, 9 cases with neurological complications, 8 cases developed DIC, 68 cases were admitted to ICU, 12 cases with pulmonary edema, 10 cases with AKI and 7 cases with maternal mortality (Table 7).

Descriptive analysis of the studied cases according to NICU admission:

Significantly higher incidence of NICU admission among severe PET (Table 8).

Distribution of the studied cases according to severity:

But by the end of this study 50 cases of mild PET were lost during follow up and 70 cases of mild PET converted to severe form (Table 9).

Table 6. Comparative analysis of the two studied groups according to mode of delivery.

\begin{tabular}{|c|c|c|c|c|c|c|c|c|}
\hline & \multicolumn{2}{|c|}{$\begin{array}{c}\text { Total } \\
(n=450)\end{array}$} & \multicolumn{2}{|c|}{$\begin{array}{c}\text { Mild } \\
(\mathrm{n}=330)\end{array}$} & \multicolumn{2}{|c|}{$\begin{array}{c}\text { Severe } \\
(n=120)\end{array}$} & \multirow{2}{*}{$x^{2}$} & \multirow{2}{*}{$\mathbf{P}$} \\
\hline & No. & $\%$ & No. & $\%$ & No. & $\%$ & & \\
\hline \multicolumn{9}{|c|}{ Outcome delivery } \\
\hline Normal & 32 & 7.11 & 20 & 6.1 & 12 & 10.0 & \multirow{2}{*}{$41.503^{*}$} & \multirow{2}{*}{$<0.001^{\star}$} \\
\hline C.S. & 418 & 92.89 & 310 & 93.9 & 108 & 90.0 & & \\
\hline
\end{tabular}

Table 7. Distribution of maternal complication among severe cases.

\begin{tabular}{lcc}
\hline & No. & $\%$ \\
\hline Eclampsia & 20 & 4.4 \\
HELLP & 93 & 20.6 \\
Neurological complications & 9 & 2.0 \\
DIC & 8 & 1.7 \\
ICU & 68 & 15.1 \\
Pulmonary edema & 12 & 2.6 \\
AKI & 10 & 2.2 \\
Mortality & 7 & 1.6 \\
\hline
\end{tabular}

Table 8. Comparison between the two studied groups according to NICU admission.

\begin{tabular}{|c|c|c|c|c|c|c|c|c|}
\hline & \multicolumn{2}{|c|}{$\begin{array}{c}\text { Total } \\
(n=383)\end{array}$} & \multicolumn{2}{|c|}{$\begin{array}{c}\text { Mild } \\
(n=260)\end{array}$} & \multicolumn{2}{|c|}{$\begin{array}{c}\text { Severe } \\
(n=123)\end{array}$} & \multirow{2}{*}{$x^{2}$} & \multirow[t]{2}{*}{$\mathrm{p}$} \\
\hline & No. & $\%$ & No. & $\%$ & No. & $\%$ & & \\
\hline \multicolumn{9}{|c|}{ NICU admission } \\
\hline No & 258 & 67.4 & 233 & 89.6 & 25 & 20.3 & \multirow{2}{*}{$216.286^{*}$} & \multirow{2}{*}{$<0.001^{\star}$} \\
\hline Yes & 125 & 32.6 & 27 & 10.4 & 98 & 79.7 & & \\
\hline
\end{tabular}

Table 9. Distribution of the studied cases according to severity $(n=500)$.

\begin{tabular}{ccc}
\hline & No. & $\%$ \\
\hline Severity & & \\
Mild & 380 & 76.0 \\
Severe & 120 & 24.0 \\
\hline
\end{tabular}




\section{Discussion}

In agreement with our study also, Siveska, and Jasovic, [21] conducted a prospective study upon 400 pregnant women. They were divided in three groups: 300 normo-tensive pregnancies (controls), 67 pregnancies with mild PET and 33 pregnancies with severe PET. They reported that severe cases occurred at earlier gestational age and more common among primigravida but did not exhibit significant difference between the patients as regarding maternal age.

In contrast to our study, Sharma, et al., [22] studied the incidence of abruptio placenta among PET cases who were complicated by SGA via a retrospective cohort study of 8927 singleton pregnancies, they found that women with preeclampsia and SGA infants were more likely to experience abruption than preeclamptic women with appropriate for gestational age (AGA) (5.3\% versus 3.0\%). While we had a higher incidence of abruptio placenta totally about $16 \%$. This can be attributed to lack of good antenatal care and delay for seeking medical advice.

In contrast to our study, Weiler, et al., [23] by using aretrospective cohort study of 176 cases of severe pre-eclampsia, showed that $39 \%(n=68)$ found to be complicated with fetal growth restriction (IUGR). But in our study we had a percentage of $79.2 \%$, and this higher percentage of IUGR cases may be attributed to a huge sample size in our study.

Duley, et al., [24] conducted a study on 397 women and reported that magnesium sulphate was associated with fewer maternal deaths and was better in preventing further seizures than lytic agents mixture (usually promethazine, chlorpromazine and pethidine) which agrees with our study that adopted giving Mgso4 to all severe cases.

Haram, et al., [25] used clinical reports and reviews published between 2000 and 2008 and Pub Med and Cochrane data bases and reported that in cases with HELLP syndrome delivery is a must to gaurde against maternal and fetal morbidity and mortality with preference of vaginal delivery more than C.S. if the cervix is favourable.

In contrast, at our study the incidence of C.S rate was significantly higher in both groups and about 418 cases and only 32 cases occurred before the age of medicolegal viability were candidate to vaginal delivery if possible.

In 24 - 34 weeks of gestation, most studies prefer a single course of corticosteroids therapy for fetal lung maturity preferring dexamethasone. And this agrees with our study but we use only dexamethasone for lung maturity.

Ramos Amorim, et al., [26] found that of 325 women with severe PET only 55 found to have one or more complications (16.9\%); but there were no maternal deaths.

In contrast to our study there were 20 cases of eclampsia (4.4\%), 93 cases of HELLP syndrome (20.6\%), 9 cases with neurological complications $(2.0 \%), 8$ cases developed DIC (1.7\%), 68 cases were admitted to ICU (15.1\%), 12 cases with pulmonary edema (2.6\%), 10 cases with $\mathrm{AKI}(2.2 \%)$ and 7 cases with maternal mortality (1.6\%). This can be due to large number of cases in our study 
and also to the fact that all sever and/or complicated cases were referred to our hospital and may be at late time.

Aabidha, et al., [27] used a descriptive study which was conducted in a rural secondary referral center from August 2010 to July 2011 and reported that 93 women of the 1900 women found to be PET and the most common neonatal complications was pre-maturity $(23.65 \%)$, intra uterine growth restriction $(9.67 \%)$ and intra uterine demise of the fetus (8.6\%).

In contrast to our study, NICU admission and prematurity (32.6\%), intra uterine growth restriction (19\%) and intra uterine demise of the fetus (13.4\%).This higher incidence of fetal complications may be due to lack of good antenatal follow up of PET cases.

\section{Conclusions}

1) Regarding diagnosis, single reading of blood pressure is not reliable as cases may improve or even discharge.

2) Recent studies have demonstrated minimal to no influence of the severity of proteinuria on pregnancy outcome in preeclampsia; management of fetal growth restriction (FGR) is similar in pregnant women with or without preeclampsia [12] [13].

3) According to ACOG guidelines methyldopa, labetalol, beta blockers (other than atenolol) and slow release nifedipine are considered as appropriate treatment.

4) Regarding corticosteroids, ACOG recommended that women with severe preeclampsia receiving expectant management at $340 / 7$ weeks or less of gestation, should receive corticosteroids for fetal lung maturity. The same was done in our study and was associated with good neonatal outcome.

5) Regarding HELLP syndrome, the same way of management was adopted.

6) Eclampsia should be treated with intravenous magnesium sulfate as a first-line agent. A loading dose of $4 \mathrm{~g}$ should be given by an infusion pump over 5 - 10 minutes, followed by an infusion of $1 \mathrm{~g} / \mathrm{h}$ maintained for 24 hours after the last seizure. Magnesium sulfate in our study was also given only to severe cases not to mild cases.

7) When delivery is indicated, vaginal delivery can often be accomplished, but this is less likely with decreasing gestational age.

8) In our study the complications of CS itself were wound infection in 53 cases and parietal wall hematoma in 10 cases, only 2 cases of them were re operated upon them.

\section{Acknowledgements}

The authors are thankful to the Obstetrics and Gynecology Department, Faculty of Medicine, Alexandria University.

\section{Ethical Approval}

This study was approved ethically by ethics committee for the scientific research. 
All Institutional and National Guidelines for the care and use of animals (insects) were followed.

\section{Compliance with Ethics Requirements}

All Institutional and National Guidelines for the care and use of animals (insects) were followed.

\section{Authors' Contributions}

DE designed the study and performed data collection and analysis. MR interpreted and supervised the Lab analysis results. NE and NH supervised the clinical examinations and US findings. DE wrote the manuscript. All authors were involved in the revision of the manuscript.

\section{Conflicts of Interest}

The authors have declared no conflict of interest.

\section{References}

[1] Laganà, A.S., Favilli, A., Triolo, O., Granese, R. and Gerli, S. (2016) Early Serum Markers of Pre-Eclampsia: Are We Stepping Forward? The Journal of Maternal-Fetal \& Neonatal Medicine, 29, 3019-3023. https://doi.org/10.3109/14767058.2015.1113522

[2] Wallis, A.B., Saftlas, A.F., Hsia, J. and Atrash, H.K. (2008) Secular Trends in the Rates of Preeclampsia, Eclampsia, and Gestational Hypertension, United States, 19872004. American Journal of Hypertension, 21, 521-526. https://doi.org/10.1038/ajh.2008.20

[3] Duley, L. (2009) The Global Impact of Pre-Eclampsia and Eclampsia. Seminars in Perinatology, 33, 130-137. https://doi.org/10.1053/j.semperi.2009.02.010

[4] Porreco, R.P. and Barkey, R. (2010) Peripartum Intensive Care. The Journal of Maternal-Fetal \& Neonatal Medicine, 23, 1136-1138. https://doi.org/10.3109/14767058.2010.490890

[5] Goldenberg, R.L., Culhane, J.F., Iams, J.D. and Romero, R. (2008) Epidemiology and Causes of Preterm Birth. Lancet, 371, 75-84. https://doi.org/10.1016/S0140-6736(08)60074-4

[6] Sibai, B., Dekker, G. and Kupferminc, M. (2005) Pre-Eclampsia. Lancet, 365, 785799. https://doi.org/10.1016/S0140-6736(05)17987-2

[7] Wagner, R., Miller, S. and O’Shaughnessy, A. (2004) Area Wide Electronic Booking: a Revolution in the Management of Health and Well Being. Studies in Health Technology and Informatics, 100, 169-173.

[8] National High Blood Pressure Education Program (2000) Report of the National High Blood Pressure Education Program Working Group on High Blood Pressure in Pregnancy. American Journal of Obstetrics and Gynecology, 183, S1-S22. https://doi.org/10.1067/mob.2000.107928

[9] American College of Obstetricians and Gynecologists (2013) Hypertension in Pregnancy. Report of the American College of Obstetricians and Gynecologists' Task Force on Hypertension in Pregnancy. Obstetrics \& Gynecology, 122, 1122 1131. https://doi.org/10.1097/01.aog.0000437382.03963.88 
[10] Jeyabalan, A., Powers, R.W., Durica, A.R., Harger, G.F., Roberts, J.M. and Ness, R.B. (2008) Cigarette Smoke Exposure and Angiogenic Factors in Pregnancy and Preeclampsia. American Journal of Hypertension, 21, 943-947. https://doi.org/10.1038/ajh.2008.219

[11] Karumanchi, S. A. and Levine, R. J. (2010) How Does Smoking Reduce the Risk of Preeclampsia? Hypertension, 55, 1100-1101. https://doi.org/10.1161/HYPERTENSIONAHA.109.148973

[12] Dulak, J., Deshane, J., Jozkowicz, A. and Agarwal, A. (2008) Heme Oxygenase-1 and Carbon Monoxide in Vascular Pathobiology. Circulation, 117, 231-241. https://doi.org/10.1161/CIRCULATIONAHA.107.698316

[13] Fisher, S.J. (2015) Why Is Placentation Abnormal in Preeclampsia? American Journal of Obstetrics and Gynecology, 213, S115-S122.

https://doi.org/10.1016/j.ajog.2015.08.042

[14] George, E.M. and Granger, J.P. (2011) Endothelin: Key Mediator of Hypertension in Preeclampsia. American Journal of Hypertension, 24, 964-969. https://doi.org/10.1038/ajh.2011.99

[15] Maynard, S.E., Venkatesha, S., Thadhani, R. and Karumanchi, S.A. (2005) Soluble Fms-Like Tyrosine Kinase 1 and Endothelial Dysfunction in the Pathogenesis of Preeclampsia. Pediatric Research, 57, 1-7. https://doi.org/10.1203/01.PDR.0000159567.85157.B7

[16] Palei, A.C., Spradley, F.T., Warrington, J.P., George, E.M. and Granger, J.P. (2013) Pathophysiology of Hypertension in Pre-Eclampsia: A Lesson in Integrative Physiology. Acta Physiologica, 208, 224-233. https://doi.org/10.1111/apha.12106

[17] Powe, C.E., Levine, R.J. and Karumanchi, S.A. (2011) Preeclampsia, a Disease of the Maternal Endothelium: The Role of Antiangiogenic Factors and Implications for Later Cardiovascular Disease. Circulation, 123, 2856-2869. https://doi.org/10.1161/CIRCULATIONAHA.109.853127

[18] Venkatesha, S., Toporsian, M., Lam, C., Hanai, J., Mammoto, T., Kim, Y.M., et al. (2006) Soluble Endoglin Contributes to the Pathogenesis of Preeclampsia. Nature Medicine, 12, 642-649. https://doi.org/10.1038/nm1429

[19] Kotz, S., Balakrishnan, N., Read, C. and Vidakovic, B. (2006) Encyclopedia of Statistical Sciences. 2nd Edition, Wiley-Interscience, Hoboken.

[20] Kirkpatrick, L. and Feeney, B. (2013) A Simple Guide to IBM SPSS Statistics for Version 20.0. Student Edition, Wadsworth, Cengage Learning, Belmont.

[21] Jasovic-Siveska, E. and Jasovic, V. (2015) Fetal Growth and Body Proportion during Pre-Eclamptic Pregnancy. Obstetrics \& Gynecology International Journal, 2, 91-98. https://doi.org/10.15406/ogij.2015.02.00038

[22] Sharma, K.J., Esakoff, T.F., Guillet, A., Burwick, R.M. and Caughey, A.B. (2017) Pregnancies Complicated by Both Preeclampsia and Growth Restriction between 34 and 37 Weeks' Gestation Are Associated with Adverse Perinatal Outcomes. The Journal of Maternal-Fetal \& Neonatal Medicine, 30, 2342-2345. https://doi.org/10.1080/14767058.2016.1248394

[23] Weiler, J., Tong, S. and Palmer, K.R. (2011) Is Fetal Growth Restriction Associated with a More Severe Maternal Phenotype in the Setting of Early Onset Pre-Eclampsia? A Retrospective Study. PLOS ONE, 6, e26937. https://doi.org/10.1371/journal.pone.0026937

[24] Duley, L., Gülmezoglu, A.M. and Chou, D. (2010) Magnesium Sulphate versus Lytic Cocktail for Eclampsia. The Cochrane Database of Systematic Reviews, vol, Article No. CD002960. https://doi.org/10.1002/14651858.CD002960.pub2 
[25] Haram, K., Svendsen, E. and Abildgaard, U. (2009) The HELLP Syndrome: Clinical Issues and Management. A Review. BMC Pregnancy and Childbirth, 9, Article No. 8. https://doi.org/10.1186/1471-2393-9-8

[26] Ramos Amorim, M.M., Katz, L. and de Almeida, S.T. (2016) 19 Accuracy of Fullpiers Score for Prediction of Morbidity/Mortality in Patients with Severe Preeclampsia in Northeastern Brazil: Medical Complications of Pregnancy Related to Hypertensive Syndromes. Pregnancy Hypertension, 6, 187.

https://doi.org/10.1016/j.preghy.2016.08.101

[27] Aabidha, P.M., Cherian, A.G., Paul, E. and Helan, J. (2015) Maternal and Fetal Outcome in Pre-Eclampsia in a Secondary Care Hospital in South India. Journal of Family Medicine and Primary Care, 4, 257-260.

https://doi.org/10.4103/2249-4863.154669 